International JOURNAL OF MULTidisciplinary RESEARCH AND ANALysis

ISSN(print): 2643-9840, ISSN(online): 2643-9875

Volume 05 Issue 02 February 2022

DOI: 10.47191/ijmra/v5-i2-28, Impact Factor: 6.072

Page No. 436-439

\title{
The Importance of Mathematics in the Digital Age
}

\section{Khabiba K. Sarimsakova}

Candidate of physical and mathematical sciences, Associate Professor of the Mathematic Modelling and Information Technologies Department, The University of World Economy and Diplomacy.

ABSTRACT: There is a well-known statement by A. Einstein that there are two ways to live this life. The first, to consider that miracles do not happen, the other, to consider that everything around is a miracle.

These words can be paraphrased in relation to mathematics. There are two ways of thinking: some believe that mathematics is necessary in all spheres of human activity and that it teaches the brain to think logically, thereby helping to put both human thoughts and activities in order. Others, on the contrary, believe that mathematics is out of date and that high-tech machines are gradually taking its place. Which one is right? The article attempts to reflect on this topic.

KEY WORDS: mathematics, digital technology, digitalization of the economy, education, academic training, teaching mathematics, exam, rationality, irrationality, STEM, the modern world.

\section{INTRODUCTION}

The end of the $X X$ and the beginning of the XXI century was a period of active implementation of digital technologies (DT) in any sphere of human activity. Today, it is almost impossible to find an industry in which digital technologies are not involved. Despite the proven effectiveness of the use and practicality of utilizing digital technologies, most people and even specialists, when using absolutely all types of modern digital technologies, have an idea that mathematical skills are unnecessary and ineffective.

Even among certain scientific circles, the opinion has arisen that classical mathematics, which is taught in universities, no longer corresponds to modern trends in the development and implementation of DT. Allegedly, the existing courses of classical mathematics are viewed by students as too abstract and irrelevant. And this phenomenon hinders effective preparation for the conditions of the modern labor market. Most experts believe that a large gap has formed between the modern realities of using mathematics in DT and teaching classical mathematics in educational institutions [1].

\section{THE MAIN FINDINGS AND RESULTS}

According to Dutch experts, mathematical skills are no longer in demand and a priority criterion when applying for a job, even with the constant use of DT [2].

But, as usual, there is also the opposite opinion on this matter. For example, Honorary Professor of Mathematics Lynn Arthur Steen noted: "School mathematics is difficult, but used in simple problems, while mathematics at work is simple, but used in complex problems" [3].

Experts from the STEM (Science, Technology, Engineering, Mathematics) development program, as a result of their research, have concluded that many of the math skills taught in universities are never used by students in their work, especially when using DT.

However, most studies have shown that specialists who freely apply elements of techno-mathematical literacy that are acquired during academic study at universities, and are guided by it when processing text, numerical and graphic data, do better in their careers than people who independently study these programs. The study looked at a wide range of professions, ranging from technical consultants to specialist engineers.

It is known that in the origins of all digital technologies' functioning are simple mathematical signs and operations, introduced into the system more than 60 years ago. Take, for example, Arabic decimal digits $(0,1,2,3,4,5,6,7,8,9)$, which, when performing various arithmetic operations, effectively provided the result of actions. Thanks to digitalization, it became possible to convert these numbers into letters, and later into whole texts. Then these seemingly "simple" mathematical symbols and operations were used to convert numbers to colors, various sounds, and images, etc. thus, 3D, 4D, 5D effects appeared. 


\section{The Importance of Mathematics in the Digital Age}

Scientists, through the interaction of elements of logic, mathematical operations and symbols, have invented a platform for creating computer programs. They began to perform matrix operations and translate functional elements of programs into various codes, such as 11000100, 0110111110, 00101100, etc. This helped specialists to find a way to encrypt a large amount of information and place it compactly on DT devices [4].

These schemes have become fundamental in the development and improvement of digital technologies. Later, the system was improved, the programs became more complicated, and their use, on the contrary, was simplified. Accordingly, the initial mathematical operations also became more complex. Over the past 60 years, these "ordinary", "simple" mathematical operations and symbols used in digital technology have contributed to a rapid and dynamic breakthrough in the field of electronics, which, in turn, is reflected in all areas of human activity. This indicates that the role of mathematics in the use of DT has always been, is and will be important. Moreover, it serves as the basis, the foundation for all these DT.

As the mathematician, Attila Egri-Nagu [4] stated: "To automate any device, we break all information into mathematical values, then reverse them, and then represent them in the form of codes and increase their level."

Despite the different opinions on the role of mathematics in connection with the widespread introduction and use of modern digital technologies, mastering the basics of the "Queen of Sciences" significantly improves the working process of each person. Experts believe that the strengthening process of the role of mathematics in the world of DT begins in universities and largely depends on the activities of teachers. Despite the noticeable advantages of automated systems over human labor, there is such a thing as the human factor. In this case, it is a factor of rapid mathematical assessment of the situation, analysis and adoption of necessary and rational measures. Such skills are injected into the minds of students only with the help of teachers. Experts believe that the regular use of the following methods by teachers will arouse great interest among students in the study of the relationship between mathematics and DT:

- immersion into the world of digital technologies and the introduction of new models of DT in the learning process, thereby keeping pace with modern technologies

- development of appropriate didactic strategies based on the widespread use of DT

- interactive interaction with students with the constant use of digital technologies

According to British experts, the use of these techniques contributes to the effective development of the curriculum in mathematics, the elements of which in the long run will allow the students themselves to build a successful career [5]. But the fact is that all these technologies will be only a background for the teacher to explain the topic. The assimilation of the material also requires painstaking mental work from students. After all, the learning process is a double-edged sword. Without feedback, all efforts can be wasted. So the semester exams at the university must be very strict. In a way, even tough. Students who were able to pass all the exams successfully, like a sponge, will absorb new knowledge and the return from them will be appropriate. This is perhaps the first and main condition for the training of good specialists. My many years of experience at the university show that the quality of graduates is strongly correlated with the quality of enrollment in the first year.

In addition, practice is required at enterprises and organizations corresponding to the chosen profession. The presence of practice, where the knowledge gained would be applied, will only increase the interest of students in the subject, will serve as a good motivation for further study. Or the reason for abandoning the wrong profession.

\section{CONCLUSION}

Based on the analysis carried out above, it can be argued that the concepts of "mathematics" and "digital world" are inseparable from each other. When it comes to training specialists who will be engaged in the creation of DT, it is natural to talk about which areas of mathematics they should study, and not about giving up the study of mathematics in general.

Generally speaking, the "Queen of Sciences" has proved, is proving and will continue to prove its significance in absolutely all spheres of human activity. As they say - the position obliges.

\section{REFERENCES}

1) Bakker, A., Kent, P., Noss, R. \&Hoyles, C. (2009). Alternative representations of statistical measures in computer tools to promote communication between employees in automotive manufacturing. Technology Innovations in Statistics Education, 3(2).

2) Bellos, A. (2014) How Not to Be Wrong: The Hidden Maths of Everyday Life by Jordan Ellenberg - review. The Guardian. http://www.theguardian.com/books/2014/jun/13/how-not-tobe-wrong-hidden-maths-jordan-ellenberg-review.

3) Clark-Wilson, A., Hoyles, C., Noss, R., Vahey, P. \&Roschelle, J. (2015) Scaling a technology-based innovation: windows on the evolution of mathematics teachers' practices. ZDM Mathematics Education: 47 


\section{The Importance of Mathematics in the Digital Age}

4) Clark-Wilson, A., Hoyles, C., \&Noss, R. (2015). Conceptualising the scaling of mathematics teachers' professional development concerning technology. 9th Congress of European Research on Mathematics Education, Prague, Czech Republic. 4th - 8th February 2015.

5) Coburn, C. (2003). Rethinking Scale: Moving Beyond Numbers to Deep and Lasting Change.

6) Educational Researcher, 32(6), 3-12.

7) Diener, C.I, Dweck, C.S. (1980) An analysis of learned helplessness: II. The processing of success Journal of Personality and Social Psychology, 39 (1980), pp. 940-952.

8) Drijvers, P, Kieran, C \&Mariotti M et al (2011) Integrating Technology into Mathematics Education: Theoretical Perspectives in Hoyles. C \& Lagrange J-B (eds) (2009) Mathematics Education and Technology- Rethinking the terrain Springer Chapter 7 pp 89- 132.

9) Education Endowment Foundation (2014) 'Scratchmaths' research project, http://educationendow.mentfoundation.org.uk/projects/scratch-programming/ accessed 27th March 2015.

10) EPSRC (2012) 'Deloitte Report' - Measuring the Economic Benefits of Mathematical Science Research in the UK http://www.epsrc.ac.uk/newsevents/news/mathsciresearch/

11) Healy, L., \&Kynigos, C. (2010). Charting the microworld territory over time: Design and construction in mathematics education. ZDM: The International Journal on Mathematics Education, 42(1), 63-76.

12) Harel\& S. Papert (eds.), (1991) Constructionism, pp. 269-394. New Jersey: Ablex Publishing Corporation. 236 Hoyles.

13) Hour of Code website http://hourofcode.com/us accessed 27th March 2015.

14) Hoyles, C. Noss, R., Kent, P. \& Bakker, A. (2010) Improving Mathematics at Work: The need for techno-mathematical literacies Routledge.

15) Hoyles, C. The proceedings of the Vth SIPEM (2012) Petrópolis, Rio de Janeiro SociedadeBrasileira de EducaçãoMatemática - SBEM pp 1-12

16) Hoyles, C., \& Lagrange, J.B. (Eds.), (2009) Mathematics education and technology: Rethinking the terrain (pp. 89-132). New York: Springer.

17) Hoyles, C., Noss, R., Kent, P., \& Bakker, A. (2013) Mathematics in the Workplace: Issues and Challenges in Damlamian, A., Rodrigues, J.F., Strässer, R. (eds.), Educational interfaces between mathematics and industry: report on an ICMI-ICIAMstudy, pp. $43-51$ New ICMI study series, pp. $43-51$.

18) Hoyles, C., Noss, R., Roschelle, J. \&Vahey, P. (2013) Cornerstone Mathematics: Designing Digital Technology for Teacher Adaptation and Scaling. International Journal on Mathematics Education (ZDM), 45 (7). p. 1057. ISSN 1863-9690.

19) Hung, D., Lim, K., \& Huang, D. (2010). Extending and scaling technology-based innovations through research: The case of Singapore. In Organisation for Economic Co-operation and Development (Ed.), Inspired by Technology, Driven by Pedagogy [electronic resource]: A Systemic Approach to Technology-Based School Innovations (pp. 89-102): OECD Publishing.

20) Institute of Mathematics and its applications (2011) Advancing the Digital Arts (report). http://www.ima.org.uk/viewltem.cfm-cit_id=383289.html

21) Institute of Mathematics and its applications. Mathematics Matters. http://www.ima.org.uk/i_love_maths/mathematics_matters.cfm.html

22) Jenkins, S. (2014) For Britain's pupils, maths is even more pointless than Latin. Guardian. http://www.theguardian.com/commentisfree/2014/feb/18/maths-more-pointless-than-latin-british-pupils-china

23) Noss, R. \&Hoyles, C. (1996) Windows on Mathematical Meanings: Learning Cultures and Computers. Dordrecht: Kluwer Academic Publishers.

24) Papert, S \&Harel I. (1991) Preface, Situating Constructionism, in Harel\& S. Papert (Eds), Constructionism, Research reports and essays, 1985-1990 (p. 1), Norwood NJ.

25) Resnick, M. (2012) Mother's Day, Warrior Cats, and Digital Fluency, Stories for the Scratch online Community, Proceedings of Constructionism 2012 Educational Technology Lab pp 52-58

26) Roesken-Winter, B. Hoyles C \&Blömeke, S. Evidence-based CPD: Scaling up sustainable interventions, ZDM Mathematics Education (2015) 47:1-12

27) Scratch website https://scratch.mit.edu/ accessed 27th March 2015.

28) Vahey, P., Knudsen, J., Rafanan, K. \& Lara-Meloy, T. (2013). Curricular Activity Systems Supporting the Use of Dynamic Representations to Foster Students' Deep Understanding of Mathematics. In C. Mouza and N. Lavigne (Eds.). Emerging Technologies for the Classroom, pp. 15 - 30. Springer, NY.

29) Weir, S. (1987). Cultivating Minds: A Logo Casebook. London: Harper. 


\section{The Importance of Mathematics in the Digital Age}

30) 5th ERME Topic Conference// Mathematics Education in the Digital Age, 5-7 September 2018, Copenhagen, Denmark, https://www.math.ku.dk/english/research/conferences/2018/meda/proceedings/MEDA_2018_Proceedings.pdf

31) "Ismathematicsrelevantintheworldofmoderndigitaltechnologies?" - McGraw - Hill (2018) / https://medium.com/learning-matters/is-maths-still-relevant-in-our-digital-world-9e45eff3f296

32) "Skillsofthe 21st century" J. Wugtand N. Parekh (2010)/ http://opite.pbworks.com/w/file/fetch/61995295/White\%20Paper\%2021stCS_Final_ENG_def2.pdf

33) LynnArthurSteen, 2000 Analysis: Challengesand Opportunities. OneHundred Years of L'Enseignement Mathématique: Moments of Mathematical Education in the Twentieth Century, Daniel Corayetal., Editors. Geneva: L'Enseignement Mathématique 2003, pp. 191-211.

34) LynnArthurSteen, 2000 Analysis: Challengesand Opportunities. One Hundred Years of L'Enseignement Mathématique: Moments of Mathematical Education in the Twentieth Century, Daniel Corayetal., Editors. Geneva: L'Enseignement Mathématique 2003, pp. 191-211.

35) "Mathematicsandthedigitalworld" - AtilaEgri-Negi/http://www.egri-nagy.hu/pdf/math_4_digital_world.pdf

36) "DoingMathematicsintheDigitalAge" - Prof. D.K. Hoyles / https://core.ac.uk/download/pdf/129741801.pdf 